\title{
The Russia - USA - EU "Triangle" and Smaller States in 2003-2004
}

\begin{abstract}
The purpose of this paper is to assess the development of relations between Russia and the two Western power centres, the United States of America and the European Union, in 2003 - 2004. It goes without saying that it would be quite problematic and risky to formulate an unequivocal evaluation of this dynamic phenomenon. The author, however, sought to identify and determine the key trends of development. This was done through a search for answers to more specific questions: what was the strategy of Russia's foreign policy, how did it interact with the goals and aspirations of the USA and EU, and, finally, toward what - convergence or alienation - did evolve the dialogue between the global power centres that are of greatest importance for the Central and Eastern European countries.

These tasks have dictated the trinomial structure of the paper. The first part deals with the changes in the Russian foreign policy strategy in recent years. It shows how, upon sensible assessment of its opportunities, Russia abandoned its former rush-about and concentrated on the inclusion of the CIS states (the Ukraine in particular) in its political orbit. The second and the third part of the paper analyse the peculiarities and ups and downs of Russia's relations with the USA and the EU respectively. Despite certain variations, the development of these relations increasingly shows signs of alienation and cooling, which were partly masked by the intention of the EU larger Member States, in particular of the Germany, to maintain good relations with Russia at any cost. Finally, a brief overview of the culminating event in the Russian-Western relations - the Ukrainian "orange revolution" is presented at the end of the paper, supplemented by a broader summarisation of the period under consideration. The underlying idea of the summary is that the so-called "value gap" has been widening in the Russian-Western relations in recent years. It forms a basis for supposing that in the future the pressures between the West and Russia should increase despite the pragmatic nature of their relations. The situation might only be changed by democratic changes in Russia itself, which at present seems hardly probable.
\end{abstract}

\section{Introduction}

Smaller countries of Central and Eastern Europe (CEE) including the Baltic States used to play a quite important role in the global politics at the time of substantial changes in the entire international system related to the shift in the relations between the key power states. It should be recognised, however, that the role has often been passive rather than active. CEE countries frequently were objects of influence and exchange rather than parties to agreements and transactions, whereas Russia and

\footnotetext{
"Prof. dr. Gediminas Vitkus - Head of the Political Science Department of the Lithuanian Military Academy, Associate Professor at the Institute of International Relations and Political Science of the University of Vilnius. Address: Šilo 5a, LT-10322 Vilnius, Lithuania, tel. +370-5-2103569, e-mail: gediminas.vitkus@tspmi.vu.lt
} 
the actual ratio between its power and the power of other global powers having interests in the region have always been decisive factors in the region.

The end of the cold war, the collapse of the Soviet Union and weakening of Russia enabled Central and Eastern Europe to implement important changes. CEE countries have successfully made use of this reflux of Russia's power and were in time to complete important economic reforms and to become members of NATO and the European Union, the main organisation of the democratic Western world. Thus more power factors were included in the affairs of the CEE security region, which today provide a more effective counterbalance to the Russian factor.

But life does not stand still and the rising of the CEE countries is followed by reemergence of the old problem: Russia is recovering too. For instance, by the end of Putin's first term of office, Russia was already able to boast both its eternal ambitions and recovering economy. In 2000-2003, Russia's GDP grew by $20 \%$, the physical volume of exports by $25 \%$, and the volume of oil, petroleum products and gas exports by $18 \%$. All in all, Russia became the world's largest exporter of energy resources ${ }^{1}$. It seems that this trend will remain in the nearest future. Oil and gas prices have been incessantly increasing in recent years and it is probable that the increase will continue both due to turbulent political processes in the Middle East and to general growth in demand.

Overall economic growth has been accompanied by increasing Russia's foreign direct investments, in particular in the energy sectors of the neighbouring countries. Russian companies, making use of the advantages of having main energy resources under their control, the energy resource transportation and power supply systems established in Soviet years, and availability of spare funds due to the situation, take an active part in the process of privatisation of energy enterprises in the Central Europe and CIS, thus gaining significant economic power in the neighbouring countries. In 2002-2003, two Russian giants - Gazprom gas concern and RAO-UES, a power suppliers' amalgamation, increased their share of the CIS and CEE markets considerably. However, the companies taking part in privatisation are not merely business entities. Russian authorities, which control $52 \%$ of the shares in RAO-UES, a power supply monopolist, and $38 \%$ of the shares in Gazprom $^{2}$, have their weighty say in their operations. Similar situation is observed in the oil supply sector that has been privatised to a larger extent. The Russian authorities hold private enterprises in leash as the government controls the oil transportation system and feel free to resort to sanctioned violence with respect to "disobedient" companies (Yukos case).

According to "The Economist", an influential British weekly journal, increasing Russia's control over the vitally important sector of the economy due to its investments would not be a bad thing if it were a merely commercial project. However, in case of Russia it is becoming a tool of political influence and, where necessary, of political pressure as well ${ }^{3}$. Therefore, "participation" of the world's other major power centres

${ }^{1}$ See: Путин В., "Послание Федеральному Собранию Российской Федерации, 16 мая 2003 года, Москва", Президент России. Официальный сайт, http://www.president.kremlin.ru/text/appears/2003/05/ 44623.shtml, 03022005.

${ }^{2}$ See: Jé M. "Moscou renoueses liens "energétiques" avec l'ex-URSS", Le Monde, 2 décembre, 2003, p.2.

3 "Ivan at the pipe", The Economist, December 9, 2004. Also see: Smith K., "Russian Energy Politics in the Baltics, Poland and Ukraine. A New Stealth Imperialism?", CSIS Report, Washington D.C., December 2004. 
in the CEE region and particularly the nature of their relations with Russia does not lose its significance, and is even increasing, in this dynamic and unstable context. This is why these relations were chosen as the main subject of this paper.

The purpose of this research project is to assess the development of relations between Russia and the two Western power centres, the United States of America and the European Union, in 2003 - 2004. It goes without saying that it would be quite problematic and risky to formulate an unequivocal evaluation of this dynamic phenomenon. The author, however, sought to identify and determine the key trends of development. This was done through a search for answers to more specific questions: what was the strategic direction of Russia's foreign policy, how did it interact with the goals and aspirations of the USA and EU, and, finally, towards what - convergence or alienation - did evolve the dialogue between the global power centres that are of greatest importance for the Central and Eastern European countries. These tasks have dictated the trinomial structure of the paper. The first part deals with the changes in the Russian foreign policy strategy in recent years. It shows how, upon sensible assessment of its opportunities, Russia abandoned its former rush-about and concentrated on the inclusion of the CIS states (the Ukraine in particular) in its political orbit. The second and the third part of the paper analyse the peculiarities and ups and downs of Russia's relations with the USA and the EU respectively. Despite certain variations, the development of these relations increasingly shows the signs of alienation and cooling, which were partly masked by the intention of the EU largest Member States, in particular of the German authorities, to maintain good relations with Russia at any cost. Finally, a brief overview of the culminating event in the RussianWestern relations - the Ukrainian "orange revolution" - is presented at the end of the paper, supplemented by a broader summarisation of the period under consideration.

\section{Putin's Project}

The last occasion in 2004 for the Russian President Putin to overview and assess his achievements and problems was a grandiose press conference held in the Kremlin on 23 December. 51 question was put by 690 Russian and foreign journalists participating in the conference, which lasted for as many as three hours. In the opinion of some observers, the conference was focussed on form (i.e. maintaining of an image of a powerful but very direct president) rather than on substance of problems ${ }^{4}$. However, despite superficiality that is characteristic of such events, the observers have also noted how emotional and aggressive were Putin's statements on foreign policy issues. Western criticism of the President's policy in the former USSR space was one of the key leitmotivs in the foreign policy discussion. Putin was indignant at, as he put it, "double standards" of the West in assessing results of elections in various countries. He said that elections in Afghanistan, Kosovo and even the US could be criticised as well. Election in the occupied Iraq on the background of military actions is something that is difficult to understand. According to Putin, however,

${ }^{4}$ Falkowski M., "Konferencja prasowa prezydenta Putina: mniej treści, więciej formy”, Komentarze OSW, 30 grudnia 2004, http://www.osw.waw.pl/pub/koment/2004/12/041230.htm, 23032005. 
when the election is taking place in a post-Soviet country, an entire "system of permanent revolutions" emerges with the election ending up in a "pink or blue or whatever revolution"s.

Putin's indignation is understandable. Events taking place during the last two years in the pot-Soviet space, in Georgia and the Ukraine in particular, were far from in line with Russia's plans and intentions. The events of 2003-2004 changed a generally favourable balance of foreign policy successes and failures of Putin's second term of office for the benefit of the latter. This is very different from the mood that had prevailed in the Kremlin just one and a half years ago, when preparations for the Russian parliamentary and presidential election were underway.

In his annual report to the State Duma on 16 May 2003, Putin outlined an impressive and powerful future for the recovering Russian state. He emphasised that Russia had already completed the most difficult period of transformation, when a threat of destruction of the state had arisen, and that Russia regained its legitimate place among the most powerful and reputable states of the world. Among achievements substantiating such statement, Putin mentioned the recognition of Russia as a key player in the global antiterrorist coalition, the official invitation to become a member of the G-8 in June 2002, recovery of Russia's economy and successful expansion of Russian companies' operations beyond the country's limits. It is true that Putin himself acknowledged in his report that unprecedented improvement in foreign trade conditions had formed a basis for Russia's economic growth ${ }^{6}$, however, according to him, in spite of that Russia must continue consolidation of its achievements. For this purpose, Russia's GDP must be doubled in ten years, strategic partnership with the European Union has to be further developed, and Russia must become a part of the global economy by joining the World Trade Organisation. However, the most interesting - and the most threatening - thing in Putin's speech was his statement “... and I wish to tell you openly that we consider CIS area to be the area of our strategic interests" .

This was quite a significant and new turn considering the fact that up until then Russia's post-Soviet foreign policy had been characterised by the lack of a clear strategic resolution on its key priorities. Throughout the past decade, in its relations with the West Russia attempted, by different geopolitical combinations, to gain a status of an equal and important partner. Russia tried to interfere with the Balkan and Middle East affairs; at one time, it propagated the idea of a multi-pole world; it tried to flirt with the states of the so-called "evil axis" - North Korea, Libya, Cuba, Iran and Iraq-and to act as an intermediary in their relations with the West. But it was a resolution of Putin after his coming to power that Russia's status as a great power would be better secured not by "balancing" other powerful countries in one form or another but by gradually gluing a new power centre of the fragments of the Soviet Union, headed by Russia, which would later help Moscow maximise its power. One may only guess at what kind of power centre it would have been. In any case, however, Putin and his associates must have had on their minds something more that the then amorphous CIS.

\footnotetext{
5 “Пресс-конференция Владимира Путина”, 23 декабря 2004 года, Москва, Кремль”, Президент России. Официальный сайт, http://www.president.kremlin.ru/appears/2004/12/23/1414_type63380type82634_81691.shtml, 08032005.

${ }^{6}$ See: Путин В. (note 1$)$.

${ }^{7}$ See: Путин В. (note 1).
} 
As shown by the events in 2003-2004, it was a double-faced project in substance. On the one hand, Russia was seeking to achieve that the neighbouring CIS states would be loyal to it and would not submit to the influence of the West, i.e. the USA or the European Union. On the other hand, these countries had to become a zone for the expansion of the recovering Russian economy. According to Dmitri Trenin, Deputy Director of the Carnegie Moscow Center, this could be a certain "combination of the Russian version of the Monroe Doctrine (which was proposed, as early as in 1992, by Yevgeni Ambartsumov, the then chairman of the Foreign Affairs Committee of the Russian Supreme Council, and which is currently supported mainly by representatives of the power structures) and the "liberal empire" project in line with the interests of major investors, advanced by Anatoli Chubais in 2003" .

Thus, one can easily see competition over the control of energy resources and their transportation means behind practically all political processes taking place in the CIS space in 2003-2004. Russia's politics in the so-called "near abroad" was aimed at maintaining and further consolidating the relatively comfortable situation. The main political economic issue was as follows: will the West manage to develop a system of supply of energy resources from the Central Asia and the Caspian Sea Basin that would constitute an alternative to the Russian system. Only two facts are sufficient in order to illustrate what is at stake.

Firstly, despite economic recovery and social stability, Russia remains highly dependent on oil and gas prices. Oil and gas account for one-fourth of Russia's GDP, almost one half of export revenues, and one-third of national tax revenues; therefore, according to "Financial Times", just a $\$ 1$ rise in the oil prices on the global market would mean $\$ 1.5$ billion in the Russia's state budget revenues, while a decline would produce a reverse effect ${ }^{9}$. Therefore, emergency of any alternative sources of supply is extremely undesirable, which, of course, is a complete contradiction to the Western interest in obtaining cheaper energy resources.

One more fact illustrating the advantage enjoyed by Russia due to the pipeline transportation system inherited from the Soviet Union. Turkmenistan, a Central Asian state that is rich in gas resources, has no other way to sell them on the global market except via Russia. Gazprom purchases gas from Turkmenistan at $\$ 44$ per $1000 \mathrm{~m}^{3}$, paying only half of the amount in US dollars and covering the remaining half by commodities produced in Russia. But then Gazprom sells the same gas, e.g. to Turkey already at $\$ 150$ per $1000 \mathrm{~m}^{3}{ }^{.10}$

Of course, it would be too great a simplification to reduce the diversity of the political process to oil, gas and pipelines. One has to add a thirst for power and an imperial tradition of "the Great Power" that has been historically characteristic of Russia and that can constitute an even stronger political motive. It has been this intermingling of rational and irrational motives that had manifested itself in Russia's foreign policy toward CIS countries in 2003-2004.

\footnotetext{
${ }_{8}^{8}$ Тренин Д., “Идентичность и интеграция: Россия и Запад в XXI веке”, Pro et Contra, 2004, т. 8, № 3, c.11, http://www.carnegie.ru/ru/pubs/procontra/Vol8n3-01.pdf , 23032005.

${ }^{9}$ Hill F., "A land too cold for a free market in energy", Financial Times, 17 October 2003, p. 21

${ }^{10}$ See: Jé M. (note 2).
} 
Putin's policy toward the Ukraine is the most glaring example of such politics balancing on the edge of rationality and irrationality. The Ukraine means the matters of a consortium for gas transportation to Germany, the dilemma of utilisation of the oil pipeline Odessa-Brody, the prospects of Russian capital investments etc. At the same time, the Ukraine is as if Russia's fate itself. Nobody knows if Putin has read Zbigniew Brzezinsky's "The Grand Chessboard", in which the Doctor of Honour of Vilnius University writes that without Ukraine Russia ceased to be an Empire, with Ukraine absorbed and subordinated Russia automatically will become the new Empire $^{11}$. Anyway, in 2003-2004 Putin concentrated his efforts and energy on "returning" the Ukraine to Russia's political orbit and to persuade or force it to enter into a broader political and economic agreement, i. e. to establish the so-called Common Economic Area including also Belarus and Kazakhstan.

However, the Ukrainian authorities were not inclined to give up its position on all these matters. The issues of ownership and profit distribution formed the essence of the gas transportation consortium. Ukraine was dissatisfied with Russia's intention to take over part of the gas pipelines. The Odessa-Brody oil pipeline built by the Ukrainians in 2000-2001 and intended to be extended up to Gdansk was a still greater headache for Russia. If used for the transportation of the Caspian oil delivered by sea, it would become an alternative oil supply to Europe and would inevitably ruin the Russian monopoly. So Russian oil companies backed by the Russian authorities started making tempting proposals to the Ukraine for the use of the pipeline in the other direction - to pump the Russian oil from Brody to Odessa for further transportation by sea to Southern Europe ${ }^{12}$.

Finally, the Common Economic Area project proposed by Moscow, which had to become a kind of customs union of the four CIS states, was interpreted by the Ukraine as a still another attempt to realize Russia's imperial ambitions. The Ukrainian government considered, and this was well founded, that the project would restrict Ukraine's opportunities for independent communication with the European Union and WTO, while Russian attempts to deny that seemed unconvincing. Moscow did not succeed in camouflaging the imperial substance of such ideas because they were imperial indeed. Moscow desired to become a gate to the post-soviet area for the EU and WTO, whereas the Ukraine resisted this instinctively.

However, this time Russia was very persistent; besides, the moment was particularly favourable. The Ukraine governed by the President Leonid Kuchma had lost favour of the West. The USA did not wish to cooperate with the government that was corrupted and secretly trading in arms. In addition, at that time the USA was preoccupied with the issues of terrorism and Iraq. The European Union, in its turn, was engaged in its internal reforms and preparations for enlargement to the East, so paid almost no attention to the Ukraine. Whereas the Russian President used a full range of diplomatic and military pressure in order to finally attain his objectives. Apart from direct persuasion in respect of Kuchma and promises to support a government's candidate in the Ukrainian presidential election at the end of 2004 and to give economic discounts, in the summer of 2003 Putin even authorized an escalation of a terri-

\footnotetext{
${ }^{11}$ See: Brzezinsky Z., The Grand Chessboard. American Primacy and Its Geostrategic Imperatives, New York: BasicBooks, 1997, p. 113

${ }^{12}$ See: Sokor V., "Teamwork and a Good Save in the Pipeline Game", Wall Street Journal Europe, 17 October, 2003, p. A9.
} 
torial conflict over the Tuzla Island in the Kerch Strait, relating its settlement to the implementation of the Common Economic Area project.

It seems that eventually the Ukraine submitted to Russia's pressure and on 19 September 2003 the Concept Paper on the Common Economic Area was signed by the four states in Yalta ${ }^{13}$. Afterwards the agreement was hastily ratified in order to further implement it through specific legal acts. All this took place with the West quite calmly observing and practically not interfering despite negative comments in the Western press by well-known experts, who also urged the West not to leave the Ukraine alone in its dealings with Russia. According to a senior fellow of the Washington-based Institute for Advanced Strategic \& Political Studies Vladimir Sokor, "this so-called Eurasian Economic Union seems intended generally to create a sheltered market for uncompetitive products, and more specifically to orient Ukraine's economy more firmly toward Russia as a means of mortgaging Ukraine's European future" ${ }^{14}$. And Robert McFarlane, who served as U.S. President Ronald Reagan's national security adviser stated that "...yet the U.S. seems so conflicted between the goal of achieving early evidence of social and political reform in Ukraine and the desire to avoid turmoil in the relationship with Moscow that it runs the risk of being left in Ukraine with little influence and diminished local ability to reform... Ukraine wants to be a Western country, but it needs help."15

The Caucasus, and Georgia in particular, became another key target of Russia's politics in the post-Soviet area in 2003-2004. Formally, the so-called Pankisi Ravine problem was the main source of disagreement between Russia and Georgia; according to the Russian authorities, Chechen fighters hide in the ravine. Russia has even threatened to invade the ravine if Georgia itself does not manage to establish order. However, in the opinion of many observers, oil is the main cause of the Russian-Georgian conflict: the Baku-Tbilisi-Ceyhan pipeline is being built across Georgian territory, which will allow pumping Caspian and maybe (in the future) Kazakhstan oil to the global market passing Russia over and acquiring another alternative to the Persian Gulf's suppliers, which are the cause of constant rise in oil prices. Therefore, this project has been strongly supported as a strategic one by both the USA and the European Union. Whereas Russia, in its turn, has attempted to destabilise Georgia and to hinder the pipeline construction. It is easier to find a pretext for interference in Caucasus that anywhere else. Therefore, Russia's interests were served both by support for separatists in Abkhazia and Southern Osetia, and the Pankisi problem. Also, in order to exert pressure, in 2002 Russia terminated the already prolonged negotiations for the removal of its military bases, although it had to finish them by the end of 2000 under the Istanbul agreement within the framework of OSCE ${ }^{16}$.

\footnotetext{
13 “Концепция формирования Единого экономического пространства, 19 сентября 2003 г.”, Президент России. Официальный сайт, http://www.president.kremlin.ru/text/docs/2003/09/52480.shtml, 2802 2005.

${ }^{14}$ Sokor V., "Standing Up to Putin's Imperial Ambitions", The Wall Street Journal Europe, 19 September, 2003, p. A9.

${ }^{15}$ McFarlane R., Ways to Prevent the Seduction in Kiev, The Wall Street Journal Europe, 10 October, 2003, p. A9.

${ }^{16}$ OSCE, "Joint Statement of the Russian Federation and Georgia, Istanbul, 17 November 1999" in OSCE Istanbul Document 1999, p. 252, http://www.osce.org/docs/english/1990-1999/summits/ istan99e.pdf, 28022005
} 
Actually, it was due to the Pankisi problem that the Georgian government received support from the USA. In the spring of 2002 the USA and Georgia agreed that the former would dislocate its military advisers in Georgia under the pretext of assisting Georgia in better controlling the Pankisi Ravine as it was suspected that it was being used by the Chechen rebels and al-Qaeda terrorists for maintaining contacts. However, it is obvious that this was a sign for Russia showing that it will not succeed in destabilising Georgia to such extent so that the pipeline construction is terminated ${ }^{17}$.

But Russia was not going to concede and it seems that in the summer of 2003 it succeeded in "cornering" the then Georgian government. At that time, due to inconsistent position of Georgia's President Eduard Shevarnadze, practically all the national energy sector fell under the Russian companies' control.AES Telasi, a US company that had controlled Georgian power distribution system, sold the controlling block of shares to a Russian giant RAO UES (a scenario similar to the Williams drama in Lithuania). Soon the Georgian government signed an agreement with the Russian monopolist Gazprom on the monopolistic supply of gas for 25 years, which caused even greater indignation of the Georgian opposition. Pressures in Georgia were also increasing pending parliamentary election in the autumn of 2003, which had to eventually show the direction of Georgia's politics. However, it seems that, as distinct from the case of the Ukraine, Russia had no clear plan as to which political forces it should support in Georgia. It looks like Shevarnadze would be more useful to it: even though he had been difficult to deal with, it was possible to force him to obey. Whereas the opposition's disposition was clearly pro-Western and it seemed that it was supported by citizens more than the then government.

Although in 2003 Russia had focused attention on strategically important issues of the Ukraine and Georgia, one more CIS member, Moldova, received exceptional attention. Today Moldova, which still cannot eliminate its Soviet heritage, is the poorest country in Europe: according to the World Bank, even Albania's indicator of the GDP per capita is three times better. A separatist conflict preventing normal development of the country is often identified as the cause of such situation.

The Organisation for Security and Cooperation in Europe (OSCE) has been trying to settle the conflict for an entire decade, however, without success. Russia, too, has been involved in the conflict since the armistice in 1992. However, it has committed itself, in the final document of the OSCE Istanbul summit, to withdraw its forces from Moldova and to liquidate its ammunition stores by the end of $2002^{18}$. Eventually the term was extended to the end of 2003. It is natural that the conflict had to be settled somehow by this time. The EU also expressed a wish to join the settlement of the conflict; it was in a position to act much more effectively than OSCE as it had larger funds at its disposal and could even offer peacekeeping troops to replace the Russian army being withdrawn. Finally, this had to become the first joint peace-keeping operation of Russia and the $\mathrm{EU}^{19}$.

${ }^{17}$ See more: Scott, P.D., "Pipeline politics: Oil behind plan for U.S. troops in Georgia", The Final Call Online Edition, 0319 2002, http://www.finalcall.com/perspectives/pipeline03-19-2002.htm, 28022005 .

${ }^{18}$ OSCE, "Istanbul Summit Declaration" in OSCE Istanbul Document 1999, p. 50, http://www.osce.org/docs/english/1990-1999/summits/istan99e.pdf, 23032005.

${ }^{19}$ See more: Lynch D., "Russia's Strategic Partnership with Europe", The Washington Quarterly, Spring 2004, p. 114-117. 
However, to the astonishment of OSCE and EU, on 17 November 2003 Russia suddenly undertook a unilateral initiative. Dmitri Kozak, Deputy Head of Putin's administration, present a draft memorandum on division of the competencies between Chisinau and Tiraspol. The purpose of the draft memorandum was to establish the Federal Republic of Moldova, an asymmetrical federation consisting of Moldova, Gagausia and Transnistria having equal legal rights, with the Russian language being the second official language along with the Romanian language. A referendum on the constitution would be held in 2004 and the general election in 2005. 2,500 Russian peacekeepers had to be left for an unlimited period of time as a guarantee of implementation of the agreement. The Federation would be demilitarised and Moldova would have no army of its own ${ }^{20}$. In substance this would mean Moldova's transformation into a federation and Russia's becoming the guarantee of its stability on a unilateral basis, thus securing an opportunity for remaining in the region indefinitely. On 24 November 2003 Putin's visit to Chisinau for a solemn signing of the memorandum had to take place. This event was meant to become a still another victory of Russian diplomacy in reintegrating the former Soviet republics.

So in the autumn of 2003 Russia's foreign policy in the countires of "nearest abrod" was increasingly showing signs of reanimation of the empire. And this was not accidental. External imperialism with respect to neighbours reflected authoritarianism which was becoming stronger within the country. Along with the striving for stronger "tying" of the neighbouring states, at the same time the Russian government started restricting democratic freedoms in the country and persecuting influential business magnates that were not loyal to the Kremlin. This was partly related to the parliamentary election scheduled for the end of 2003 and the presidential election to be held in the spring of 2004. However, as shown by later events, the essence lay not in the elections but in the more and more apparent trend for centralising Russia's governance. According to the Freedom House analyst Adrian Karatnyck, the socalled militocrats, i. e. former military and KGB men led to power by Putin ${ }^{21}$ sought not only to make use of the government positions to the maximum extent possible, so that victory in the elections is secured, but also to ensure that control over processes remains in their hands in the future.

Although the election to the State Duma were scheduled for December 2003, as early as in June the authorities closed the last independent national TV channel; the siege of Yukos oil company followed in July. Platon Lebedev, the main partner of the company's head Mikhail Khodorkovsky, was arrested and accused of fraud. Persecution of other persons related to the company and hindering of it business started. It was stated officially that Yukos had violated the laws and was practising fraud, however, the actual reasons was clearly different: statements by Yukos' head and key shareholder Khodorkovsky as to his plans to finance the election campaign of opposition parties.

In the meanwhile, criticism of Putin in the world press was becoming more active, Washington and the European leaders were being urged to use their levers of

${ }^{20}$ Бовт Г., Виноградов М., Ратиани Н., “2500 “лишних Иванов”. Молдавия сорвала план мирного урегулирования и визит Путина”, Известия, 25 ноября 2003 г., http:/www.izvestia.ru/politic/article41479, 17032005.

${ }^{21}$ See more: Karatnycky A., "Jobs for Boys: Putin's New 'Militocracy' “, The Wall Street Journal

Europe, 13 June, 2003, p. A11. 
influence in the Kremlin in order to stop the evolution toward authoritarianism in Russia. However, this did not yield any results as Putin had established good personal relations with the leaders of all main Western states, which allowed him to expect that there will be no official criticism damaging the personal relations. After returning from a visit to the USA in the autumn of 2003, Putin apparently decided that the moment was favourable for striking another blow to his main political competitor Khodorkovsky. On 25 October Khodorkovsky was arrested in a demonstratively noisy manner and imprisoned by order of an obedient Moscow court; he was still in prison at the beginning of 2005. The political atmosphere in Russia was becoming more and more oppressive as afterwards the court refused to release Khodorkovsky on bail, banned journalists and reporters from participating in the hearings and even did not allow entry of American attorneys-at-law in Russia. The world press expressed its indignation and accused Putin of lack of respect even of his own country's laws, however, there were no critical remarks on the part of the official West.

Against this oppressive background, the election to the State Duma took place on 7 December 2003; the liberal opposition experienced a crushing defeat, while Putin's political supporters won a qualified majority which was not only absolute but also sufficient for amending the Constitution. Political situation in the country was fully controllable, even the OSCE observers, though criticising the parliamentary election as "unfair", had to agree that the election results reflect the Russian society's disposition to a larger or smaller extent.

However, as shown by events later in 2004, good beginning did not make a good ending for Putin. After successful 2003, the year 2004 was much more complicated for Putin and his supporters despite that there could not be a slightest doubt or problem concerning the outcome of the presidential election planned for March 2004. It appeared that dealing with CIS countries will not be as easy as it had been within the country, because neither these countries' citizens nor the USA and EU did think that the new independent states should bean untouchable Russia's fief. The intrigue began when things started going wrong for Putin.

\section{Russia's Relations with the US in 2003-2004}

Georgia, a country key to the Caspian oil transit, was the first "battle" lost by Putin. "Lost" might be a too strict evaluation as, one way or the other, Russia did not have a clear approach toward the Georgian politics. When numerous demonstrators invaded the parliament on 23 November 2003, indignant over obviously forged results of the parliamentary election, and made Georgia's President Shevarnadze resign, Russia still tried to interfere with its intermediation mission. Russian Foreign Minister Igor Ivanov has hastily sent to Georgia, however, he did not exert any decisive influence. Shevarnadze resigned and on the next day Nino Burdzhanadze, the chairwoman of the Parliament and acting President, made an unequivocal statement to the effect that the new Georgian government will strive to restore territorial integrity, to follow the example of the Baltic states, to take a Western orientation, and to achieve Georgia's membership of the European Union and NATO. The US President George Bush confirmed, on his turn, that these Georgia's aspirations will be supported in every way possible. In his later interviews to the Western press, Shevar- 
nadze openly accused the West and the USA in particular for causing a chaos in Georgia and for forcing him to resign. But the coming into power of the pro-Western opposition was really useful to the USA's strategic interests and not at all in line with Russia's plans. Therefore, it is not surprising that open statements about the need to support Shevarnadze appeared in the Russian mas-media ${ }^{22}$.

As early as in April 2003, a conference on the consequences of the Iraq war for the Caucasus was held by the Strategic and International Research Center of the Georgetown University in Washington. More than one of the speakers at the conference predicted that it was namely Caucasus that might become an arena for serious political competition between Russia and the USA after the end of war in Iraq ${ }^{23}$. It appears that they were completely right. To tell the truth, Putin's decision on announcing CIS as a strategic interest area was a bit late as this meant a kind of challenge to the USA, which established its military aviation bases in Uzbekistan and Kirghizstan in November 2001, after the start of war against terrorism and even without objections on the part of Russia; as it has already been mentioned, in the spring of 2002 they "stepped into" Georgia as well. Without any doubt, Georgia was important to the US not only because of the above-mentioned strategic oil pipeline project but also as a yet another, reserve base near the restless Middle East - a region critical to the US.

In general, speaking about the US-Russian relation after the Cold War, one should cite James M. Goldgeier and Michael McFaul, who wrote an exhaustive study on the American policy toward Russia. According to them, America has been constantly faced with a dilemma - to what extent should it continue its policy of power balance and Russia's containment, practiced in the cold war years, and to what extent it should now undertake a new mission to help Russia become a liberal, democratic and market-economy state ${ }^{24}$. In the opinion of these authors, after the Cold War, the American policy-makers as if split into two camps of "regime transformers" and "power balancers". The former asserted that Russia must be assisted in becoming a flourishing democratic state as soon as possible, as Russia was no longer posing a military threat to America and democracies cannot be at war with each other. Investment should be promoted and Russia should be admitted to international organisations such as WTO, while helping Russia consolidate democratic institutions within the country. Then the number of nuclear heads held by Russia will be insignificant, just as it is insignificant how many of them has the UK.

Whereas the "power balancers", forming an opposition to this attitude, held that the US has no real opportunities to exert substantial influence over Russia's internal politics, therefore, the key American interest would lie in the making use of Russia's temporary weakening and creating a power balance and international security system favourable to the US. The extreme of this view manifested itself in the

\footnotetext{
${ }^{22}$ Юсин М., “Ставка на “Лиса”. В грузинском кризисе Россия вынуждена поддерживать Шеварднадзе...”, Известия, 19 ноября 2003 г., http://www.izvestia.ru/politic/article41238, 23032005.

${ }^{23}$ See more: Радио Свобода, “Война в Ираке и ее влияние на Кавказ”, http://www.svoboda.org/programs/rtl/2003/rtl.040703.asp ir http://www.svoboda.org/programs/rtl/2003/rtl.040903.asp, 2502 2005 .

${ }^{24}$ See: Goldgeier F.M., McFaul M., Power and Purpose. U.S. Policy towards Russia after the Cold

War, Washington, D.C.: Brookings Institution Press, 2003. p. 3.
} 
striving for further weakening of Russia until its final disintegration into separate sovereign $\operatorname{states}^{25}$.

As it always happens in case of emergence of extreme views, the actual policy of a state reflects a compromise between the two extremes. Indeed, in recent years' US foreign policy toward Russia directed by the President Bush one may observe as if a permanent balancing between these extremes despite considerable changes in other foreign policy sectors. At some moments, the "power balancers" prevail, to be replaced later by the "regime transformers".

It seems that in 2003, after the Iraq war, the opinion of the "power transformers" dominated the US policy toward Russia; it has been maintained that there is no sense in interfering in and criticising Russia's internal political processes as they cannot be influenced anyway. Therefore, official information about meetings of Bush and Putin in 2003 in St. Petersburg (June) and Camp David (September) only stated that discussions were limited to issues of common interest (terrorism, Iran, Iraq) and neither Bush nor other representatives of the US administration did not publicly criticise Putin for Chechnya or restrictions of democracy, although the most influential American dailies were scorching Putin's internal policy without mercy. As regards situation in CIS - if even it was discussed, it was not spoken of publicly. However, it is obvious that US and Russia's positions in this area were almost opposite. Here one may see the role of the "power balancers", who considered Georgia to be a significant achievement.

However, developments in Georgia were just a geopolitical "battle" won by the US, and by no mean a final geopolitical victory. Despite formation of a proWestern government in Tbilisi, Russia has retained a lot of instruments of influence over Georgia. It may stop supply of oil and gas to this country at any time and tighten the visa regime for Georgian citizens looking for job opportunities in Russia. It also has control over two separatist regions of Georgia, Abkhazia and South Osetia. Finally, two Russian military bases have remained in Georgia and Russia does not intend to liquidate them in the nearest future.

The fact that this geopolitical "game" has just started is also testified by another American-Russian clash, although of a slightly lesser significance - the issue of Moldova. The matter is that the signing of the memorandum on Moldova's federalisation scheduled by the Kremlin for 24 November 2003 with the participation of Putin has failed. Due to pressure by opposition and international disapproval, Moldova's President Vladimir Voronin suddenly changed his mind and stated that he would not sign the memorandum. In his speech delivered on the OSCE foreign ministers' conference in Maastricht held on 1-2 December 2003, the US Secretary of State Colin L. Powell criticised Russia severely for its failure to fulfil its obligation to withdraw its army from Moldova and to complete negotiations over the withdrawal of troops from Georgia ${ }^{26}$. In order to avoid an unfavourable resolution Russia had to take an extreme measure and to veto the decision as it had no support for its position.

\footnotetext{
${ }^{25}$ See more: Goldgeier F.M., McFaul M., p. 1-17 (note 24).

${ }^{26}$ Editorial: A Stand on Russia", The Washington Post, December 4, 2003, p. A34, http://www.washingtonpost.com/ac2/wp-dyn?pagename $=$ article \& contentId $=$ A33557-2003Dec3\&notFound $=$ true, 04032005 .
} 
However, soon after these clashes in the "balancing" style, one could observe manifestations of influence of another camp, i.e. the "regime transformers", over the US administration. The USA finally made up its mind to publicly criticise Russia's internal political processes. As the Russian authorities were increasingly restricting the freedom of speech in order to control the election campaign and had decided on final ruination of the largest oil company Yukos, the American press and various interest groups enhanced their pressure upon Bush urging him to publicly criticise Putin's internal policy and restrictions of democracy ${ }^{27}$. Eventually this aim was achieved.

At the end of January 2004 the US Secretary of State Powell arrived to Moscow for negotiations after the inauguration of the Georgian President Mikhail Saakashvili in Tbilisi. During the visit a Russian daily Izvestya published Powell's article which evoked a considerable resonance. The article contained both a diplomatic overview of the Russian-American relations and quite harsh criticism toward the Russian government. The critical fragment is presented below:

... Certain developments in Russian politics and foreign policy in recent months have given us pause.

Russia's democratic system seems not yet to have found the essential balance among the executive, legislative and judicial branches of government. Political power is not yet fully tethered to law. Key aspects of civil society - free media and political party development, for example - have not yet sustained an independent presence.

Certain aspects of internal Russian policy in Chechnya, and toward neighbors that emerged from the former Soviet Union, have concerned us, too. We recognize Russia's territorial integrity and its natural interest in lands that abut it. But we recognize no less the sovereign integrity of Russia's neighbors and their rights to peaceful and respectful relations across their borders, as well.... ${ }^{28}$

As we see two main problem issues - the problems of Russian democracy and Russia's behaviour in pot-Soviet area have been separated out in the article. These two problem nods were the main leitmotivs of the American-Russian relations and disagreements in 2004.

One should note that, in general, the American-Russian relations in 2004 developed by inertia rather than driven by any political impulses. 2004 was the year of elections, therefore both Putin and Bush were absorbed by internal policy rather than by foreign affairs. Putin was the first of the two presidents to overcome the barrier of the election on 14 March 2004. Whereas, according to the US legislation, the decisive date for Bush was November 2nd, i. e. the first Tuesday after the first Monday of November. However, not only the dates but also the very nature of elections differed. In the USA, nobody knew the result of the election and a tiring election campaign was awaiting for Bush, whereas in Russia the main problem lay in ensuring the appearance of competition to Putin as there was a threat at one moment that the opposition forces would agree

\footnotetext{
${ }^{27}$ See more: Slevin P., Baler P., "Bush Changing Views on Putin. Administration That Hailed Russian Leader Alters Course", The Washington Post, December 14, 2003, p. A26, http:// www.washingtonpost.com/ac2/wp-dyn?pagename $=$ article $\&$ contentId $=$ A625332003Dec13\&notFound=true, 04032005.

${ }_{28}$ Powell C.L., "Partnership under construction”, Izvestia, January 26, 2004, http://moscow.usembassy.gov/embassy/oped.php?record_id=7 , 0503 2005.3. Russia's Relations with the EU in 20032004
} 
among themselves and, protesting against obstacles to their election campaign created by the authorities, would simply withdraw all the candidates, leaving the choice from candidate, which would have looked not quite "aesthetic".

As neither observers nor the main candidate had any doubts over the outcome of the presidential election in Russia, the world had an opportunity to see yet another grimace of the Russian democracy. Putin even did not waste time waiting for the date of election - he made use of his constitutional right to dismiss the government and to form a new one at the end of February. However, his choice was interesting. Mikhail Fradkov, Russia's representative in the European Union was appointed new prime minister of Russia. Apart from other things, this could also mean that Russia was starting to attach greater importance to relations with the European Union, which, to tell the truth, was quite a new turn in Russian politics.

For a long time since establishing of diplomatic relations between Russia and the European Union they have been quite formal. In spite that Russian and EU summit meetings (i.e. meetings of the Russian President, the head of the Member State in presidency, and the President of the European Commission) used to take place twice in a year under the Russian and EU Partnership and Cooperation Agreement that had come into effect in 1997, the Russian government and Putin personally attributed much more importance to bilateral relations with the key Member States - the United Kingdom, France and Germany as well as Italy, although it seems that the latter was more than Russia interested in this.

The Iraq war in 2003 had a cooling effect upon relations between Vladimir Putin and Tony Blair, which had been excellent until that time, but brought Putin closer to Jacques Chirac and Gerhard Schröder. In June 2003 Putin paid a state visit to the UK. This had to be an exceptional event as the last state visit by the head of the Russian state took place as long ago as in 1874 when Tsar Alexander II visited England. It should be noted that as state visits are quite ceremonial in nature, the invitations are agreed upon very early, sometimes even two years before the visit. At the time when Putin was invited, Blair probably saw a reformer and a person to work with in Putin. However, many things changed before the time of the visit. The relations were cooled down by the Iraq war and when Blair visited Moscow in April 2003 in order to renew them, Putin even expressed a public criticism of Blair asking where was Saddam and his weapons. Although in 2003 the UK and Russia were far apart politically, however, strange as it may seem, the UK became the largest foreign investor in Russia after a British oil company BP merged successfully with its Russian counterpart TNK.

Whereas, despite political closeness, relations between Russia and France remained complicated as on trade issues falling within the scope of the EU competence France had always been among the Member States in favour of a more protectionist EU trade policy, which was unfavourable to Russia, and of making Russia's accession to the WTO more difficult ${ }^{29}$. But these contradictions did not prevent the two countries from political and even military cooperation and from carrying out

${ }^{29}$ Jack A., "Paris and Moscow close but affair may not be long-term", Financial Times, 5 April, 2003, p. 6. 
joint military exercises. In July 2003, during the visit to Moscow by the French ministers of foreign affairs and defence, Russian and French navies manoeuvred at the shores of Norway, while French and Russian fighters carried out joint exercises in Lipeck and Belarus ${ }^{30}$.

However, in 2003-2004 Russia's relations with Germany and personal relations between Putin and Schröder were particularly exceptional. Of course, Putin's fluency in German played an important role; however, interests of German energy companies, gas companies in particular, were even more significant. Importance attached to Russia by Schröder and many German businessmen is so great that good relations with the Russian authorities must be maintained at any cost. According to junge Welt daily, Russia meets $31 \%$ of Germany's demand for gas and $29 \%$ - for oi ${ }^{31}$. It should be admitted that Schröder has been consistently following this approach despite increasing authoritarian and imperialistic trends in Russian politics and constant public criticism by the German opposition and press $^{32}$, the waves of which used to rise before each meeting of Putin and Schröder. Schröder has never allowed himself to publicly criticise Putin, while energy issues have always reigned the agendas of their meetings.

For instance, during the Russian-German intergovernmental consultation in October 2003 in Yekaterinburg, a lot of time was devoted to discussions on the grandiose project of a gas pipeline built on the Baltic Sea bottom and connecting Russia with Germany. Or, for example, before Putin's and Schröder's meeting at the German-Russian economic forum in July 2004 the criticism expressed in Germany was particularly severe as authoritarianism in Russia was increasing and the newspapers often repeated the same statements - personal relations between the Chancellor and Putin is a good thing, of course, but if would be better if, in case of problems, German companies could rely upon the Russian legislation, law-enforcement system and unbiased courts and not upon the Chancellor's connections ${ }^{33}$.

In general, incredibly friendly relations between Putin and Schröder are an exceptional phenomenon as, similarly to the case of France, contradictions between Russia and Germany are quite numerous. Russia did not consistently support Germany and France on the issue of Iraq. In his interview to New York Times in October 2003, Putin said that Russia did not interfere in the disputes between the USA and Europe and that this was none of their business ${ }^{34}$. Russia did not hurry to ratify the

\footnotetext{
${ }^{30}$ Borowiec A., "France downplays jet swap with Russia", The Washington Times, 21 July, 2003, http://www.washtimes.com/world/20030714-092731-6790r.htm, 23032005.

${ }^{31}$ Elsässer J., "Kein Rapallo. Russisch-deutscher Gipfel in Jekaterinburg", junge Welt, 09.10.2003, http://www.jungewelt.de/public_php/drucken_popup.php?num $=6 \& d j a h r=2003 \& d m o n t a g=10-09$, 23032005.

${ }^{32}$ See: "Scharfe Kritik an Schröders Politik gegenüber Putin. Opposition wirft Kanzler "Doppelmoral" vor", Welt am Sontag, 14. Dezember 2003, http://www.wams.de/data/2003/12/14/210691.html, 23032005

${ }^{33}$ See for instance: "Leitartikel: Peinlicher Persilschein für Putin", Financial Times Deutschland, 0907 2004, http://www.ftd.de/pw/in/1089192463628.html?nv=op\%20, 11072004.

${ }^{34}$ Путин В., "Интервью американской газете "Нью-Йорк Таймс", 4 октября 2003 года, Ново-Огарево", Президент России. Официальный сайт, http://www.president.kremlin.ru/text/appears/2003/10/53439.shtml, 23032005.
} 
Kyoto Protocol ${ }^{35}$ strongly supported by Germany. Finally, not everybody in the German government was in favour of such friendship. For example, Joschka Fischer, Deputy Chancellor and Minister of Foreign Affairs, has always been more reserved and critical with respect to Russia. He was quite critical - to the extent permitted by the rules of diplomacy - during his visit to Kaliningrad and Moscow at the beginning of $2004^{36}$.

Hwever, despite sincerity and friendliness of communication between Putin and the leaders of the key EU Member States, this proved to be not enough as Russia's relations with the EU were becoming more diverse and important. Therefore, the Russian government's attitude toward the EU started changing ${ }^{37}$. This was apparent already in 2002 when the first Russia's conflict with the European Union as an entity over the Kaliningrad transit took place ${ }^{38}$. Then France, Spain, Italy and Greece as the EU Member States interested more in good relations with Russia than in the protection of interests of the candidate countries such as Lithuania attempted to block the proposals on Kaliningrad transit drafted by the European Commission. Preferences to Russia at the expense of Lithuania were sought, as, in case of meeting of Russia's demands, Lithuania would not be able to join the Schengen area. However, these actions were not met with approval on the part of other EU Member States. A compromise was nevertheless reached without infringing the principles proposed by the Commission.

The European Union as an entity is important for Russia, firstly, because foreign trade of the Member States falls within the scope of its competence. Even before the EU enlargement as much as $37 \%$ of Russian exports went to the ES, jumping above $50 \%$ after the enlargement. The EU is the main market for Russia's most important commodity - energy resources. The EU accounts for 53\% of Russian oil and 63\% of Russian gas exports, which meet approx. 20\% of total EU demand for these products ${ }^{39}$. Therefore, the prospects of Russia's negotiations for WTO membership depend on the general EU position.

\footnotetext{
${ }^{35}$ The Kyoto Protocol is an amendment to the United Nations Framework Convention on Climate Change (UNFCCC), an international treaty on global warming. It also reaffirms sections of the UNFCCC. Countries which ratify this protocol commit to reduce their emissions of carbon dioxide and five other greenhouse gases, or engage in emissions trading if they maintain or increase emissions of these gases. A total of 141 countries have ratified the agreement. Notable exceptions include the United States and Australia. The formal name of the proposed agreement, which reaffirms sections of the UNFCCC, is the Kyoto Protocol to the United Nations Framework Convention on Climate Change (http://www.cnn.com/SPECIALS/1997/global.warming/stories/treaty). It was negotiated in Kyoto, Japan in December 1997, opened for signature on March 16, 1998, and closed on March 15, 1999. The agreement came into force on February 16, 2005 following ratification by Russia on November 18, 2004.

${ }^{36}$ See for instance: Donath K-H., "Eine Kaltfront zwischen Berlin und Moskau", Die Tageszeitung, 14. Feb 2004, http://www.taz.de/pt/2004/02/14/a0116.nf/textdruck, 23032005 or Champion M., "Europe May Face Divisions Over Russia", The Wall Street Journal Europe, 18 February 2004, p. A3.

${ }^{37}$ See more: Šleivytė J., “ Russia's Alignment with Europe: Pursuing the Euro-Atlantic Agenda?", Lithuanian Annual Strategic Review 2003, Vilnius: Lithuanian Military Academy, 2004, p. 155-157, http://beta.lka.lt/ serveris/biblioteka/KNYGOS/strategine apzvalga angl 2003.pdf, 01122004.

${ }^{38}$ BNS, "V. Landsbergis Rusijos veiksmuose ižvelgia bandymus suskaldyti ES vienybę", $2002 \mathrm{~m}$. rugsėjo 30 d. Also see: Sirutavičius V., Toločkienè I., "Strategic Importance of Kaliningrad Oblast of Russian Federation", Lithuanian Annual Strategic Review 2002, Vilnius: Lithuanian Military Academy, 2003, p. 196-214. http://beta.lka.lt/ serveris/biblioteka/KNYGOS/strategine_apzv_a.pdf, 01122004.

39 "Economic and Trade" in The European Commission's Delegation to Russia, http://www.delrus.cec.eu.int/en/p_216.htm, 23032005.
} 
Secondly, geographical closeness is the reason for increased Russia's attention to the Europe. After the EU enlargement in 2004, Russia borders with as much as five EU Member States. Geographical closeness both creates pre-conditions for intense trade and enhances the importance of security problems starting from the "great politics" and ending with cultural exchange and people's contacts. Border control, regional conflicts, fighting against organised crime etc. become common interests, most of which fall within the competence of the EU and not individual Member States. One should also take into account that despite a split on the issue of Iraq war the Member States are inclined to continue the development of a common EU security policy. In the summer of 2003, EU High Representative for the Common Foreign and Security Policy (CFSP) Javier Solana prepared, for the first time in the history of the EU, the European Security Strategy ${ }^{40}$, which was unanimously approved by the Member States.

Therefore, the year 2003 could be considered the beginning of Russia's attempts to develop qualitatively new relations with the EU. The eleventh Russian-EU summit meeting held in May 2003 in St. Petersburg gave its approval of the Russian initiative on transferring EU-Russian relations to new qualitative level. The declaration adopted by the meeting states that Russia and EU will develop, within the framework of the Partnership and Cooperation Agreement, four pan-European areas: economic; freedom, security and justice; science and education; and external security. The declaration also mentions higher institutionalisation of the EU-Russian relations and facilitation of the visa regime in the long term ${ }^{41}$.

Thus a promising declaration was adopted and a lost of congratulations and toasts proposed in St. Petersburg ${ }^{42}$, however, as shown by further course of events, in substance this was just a collection of nice intentions. Neither the European Union nor the EU were prepared to implement these actions in the nearest future. The twelfth Russian-EU summit meeting that took place on 6 November 2003 did not bring any substantial changes to the situation formed after the St. Petersburg meeting. Knowing that the four-area concept has a symbolic rather than actual meaning, only specific and relatively small projects were discussed at the summit meeting. The press release published by the European Commission before the meeting stated that the meeting would promote an energy dialogue, discuss the prospects of Russia's joining the WTO, approve of an agreement on cooperation between Europol and the Russian Ministry of Interior, consider the issues of future visa-free regime between Russia and the EU etc. ${ }^{43}$

\footnotetext{
${ }^{40}$ See: "A secure Europe in a better world. European Security Strategy", Document proposed by Javier Solana and adopted by the Heads of State and Government at the European Council in Brussels on 12 December 2003, http://www.iss-eu.org/solana/solanae.pdf, 23032005.

${ }^{41}$ EU-Russia Summit, Joint Statement, St. Petersburg, 31 May, 2003, http://www.delrus.cec.eu.int/ en/p_234.htm, 18032005 .

${ }^{42}$ The most famous phrase was said by the President of the European Commission Romano Prodi that "the EU and Russia were bound together like "caviar and vodka". See: Dempsey J., Jack A. "Holding operation' rewards Putin for pro-western stance ahead of elections", Financial Times, June 2, 2003, p. 8.

${ }^{43}$ See: European Commission, "EU-Russia Summit (Rome, 6 November 2003)", Brussels, 04 November 2003 in The European Commission's Delegation to Russia, http://www.delrus.cec.eu.int/ en/p_399.htm, 23032005 .
} 
It should be noted that the Rome summit had aroused increased observers' attention from the very beginning. At that time, passions and discussions in Europe over the arrest of Yukos' CEO Khodorkovsky and Russia's future remained heated. Indeed, the Rome summit, in a certain sense, did not "disappoint" lovers of sensations and provided several relatively unexpected developments connected with the manifestations of pro-Russian lobbying within the European Union itself. When journalists put a question to Putin concerning the rule of law in his country as well as the Yukos scandal and situation in Chechnya, the Italian Prime Minister Silvio Berlusconi interfered expressing, in substance, solidarity with the Kremlin's official position toward Chechnya.

Nobody was surprised that Berlusconi continued trying to make friends with Putin, even more zealously than Chancellor Schröder, however, this time the Italian Prime Minister was representing the entire EU and not only Italy. Therefore, his decision to undertake the role of Putin's advocate at the final press conference of the summit meeting evoked a severe reaction. Berlusconi's behaviour aroused at least surprise, if not indignation, of other EU Member States and candidate countries. On the next day even the European Commission decided to take an unprecedented action by publishing a statement that comments by a prime minister of the Member State holding presidency of the EU do not coincide, in all respects, with the EU's position ${ }^{44}$. Whereas the German press openly mocked Berlusconi urging to isolate this "political fool from Rome" (Indem sie den Polit-Narren von Rom isoliert)" 4 . Finally, the Council of the European Union gave an unsatisfactory evaluation of the results of the Russian-EU summit meeting because they did not reflect the Chechen problem ${ }^{46}$. Although it should be noted that poor Italian presidency was not recorded in any way in the official EU information sources and documents.

Berlusconi's "jokes" obscured, to some extent, another important aspect of the Rome summit: it was the last meeting of such level in which EU participated as a union of 15 Western states. Next time Putin was going to speak with the heads of states representing interests of twenty-five and not fifteen EU Member States. It was namely this problem that emerged at the top of the agenda of the EU-Russian relations at the beginning of 2004. Both the European Commission and the Russian government started preparations. In the opinion of the Commission, the Partnership and Cooperation Agreement between the EU and Russia, which establishes, inter alia, bilateral trade relations, should be automatically extended to cover the acceding countries. Whereas Russia presented to the Commission a list of 14 items - demands that had to be met in order to get Russia's consent to extension of the Agreement to ten more countries acceding to the US on 1 May 2004. Russia demanded that US would com-

${ }^{44}$ BBC News World Edition, "EU dismay at Berlusconi comments", 6 November 2003, http:// news.bbc.co.uk/2/hi/europe/3248995.stm, 23022005.

${ }^{45}$ Winter M. "Keine Komplizenschaft", Frankfurter Rundschau, 8 November, 2003; Also see: "Zwei dicke Freunde", Die Welt, 2003, n. 47, http://zeus.zeit.de/text/2003/47/Berlusconi, 23032005.

${ }^{46}$ von Büchner G., "EU geht auf größere Distanz zu Russlands Führung", Berliner Zeitung, 18

November 2003, S. 6. 
pensate it for estimated losses amounting to approx. EUR $150 \mathrm{~m}$ per annum to be incurred in connection with termination from 1 May 2004 of previous trade agreements with the candidate countries. The 14 items also included the issue of visa-free regime as up until then Russians needed no visas to most of the candidate countries (e.g. Cyprus) as well as the issue of unsatisfactory situation of Russian minorities in Latvia and Estonia.

However, the European Commission did not yield to Russia's pressure and presented, on its turn, a 17-page description of unsettled issues in the EU-Russian relations to the Council and the European Parliament ${ }^{47}$. It included violations of the principles of democracy, human rights and the rule of law, unsigned agreements on the state border with Latvia and Estonia, subsidising of the national energy sector, delay in ratification of the Kyoto Protocol, reluctance to acknowledge navigation and nuclear energy safety standards, and unjustified taxation of the European airlines the airplanes of which pass the Russian territory in transit.

Reports had appeared in the press that the signs of crisis were apparent in the EU and Russian relations, that contradictions in the European Union itself arose due to relations with Russia, and that Russia was even considering an option of Europe's energy blockade ${ }^{48}$, which it had just practiced in February in respect of brotherly Belarus. To tell the truth this latter action was aimed not at forcing the dictator Lukashenko to restore democracy but to show him who is the real master of the situation, at the same time sending a signal to entire Europe. However, the negotiations at the end of April 2004 during the visit of the President of the Commission Romano Prodi and seven commissioners in Moscow, held behind the closed doors, finally ended successfully, and similar assumptions appeared to be considerably exaggerated. A compromise was reached by agreeing on EU's support for Russia in acceding WTO and by Russia's committing itself to ratify the Kyoto Protocol and to start a gradual liberalisation of the national energy resources market. All these decisions were approved at a regular official Russian-EU summit meeting held in Moscow on 21 May 2004.

What conclusions can be drawn from this episode? Firstly, the relations between EU and Russia were still not characterised by a strategic depth. The declarations made at St. Petersburg including the four areas and the visa-free regime remain a long-term vision as the issues actually resolved were related to trade, transport, environmental protection, finance and other low politics issues. Whereas striking differences on the high-politics and value level remain. These differences probably arise from fundamentally different nature of the EU and Russia as international political players and not only from differences in opinions.

\footnotetext{
${ }^{47}$ See: Communication from the Commission to the Council and the European Parliament on relations with Russia (COM(2004) 106 09/02/04), http://www.europa.eu.int/comm/external_relations/russia/russia_docs/com04_106_en.pdf, 23032005.

${ }^{48}$ See: Ridderbusch K., "Beziehungen zwischen Moskau und EU sind angespannt", Die Welt, 14. Februar 2004, http://www.welt.de/data/2004/02/14/237316.html, 200503 23; "Russland: Beziehungen zur EU immer angespannter", Die Presse, 18. Februar 2004, http://www.diepresse.com/ textversion_article.aspx?id=405533 , 2303 2005.; Champion M., "Europe May Face Divisions Over Russia “, The Wall Street Journal Europe”, 18 February, 2004, p. A3; Dorner J., “ Die EU ist Putins Dauerproblem", Bremer Nachrichten, 4. März, 2004.
} 
The European Union is a unique modern amalgamation of states based not only on pragmatic interests but also on common values. For example, unlike the USA, for the EU is much more difficult "not to notice" violations of democratic procedures and the rule of law in Russia, to keep silent about and not to respond to evidence on lamentable state of human rights in Chechnya reaching Europe on a regular basis. Therefore, forms of cooperation with the states not forming part of the EU depend much upon the extent to which the partner is willing to recognise common value grounds.

But, on the other hand, European Union is not an entity confining itself to defence of values. It can be a very hard nut to crack in negotiations over specific issues falling within the scope of its competence. Therefore, Russia's urge to draft a specific action plan for the introduction of visa-free regime was very quickly met with Brussels' categorical disagreement on the grounds that Russia does not meet a multitude of criteria (starting from border guard and ending with readmission agreements) applicable to countries wishing to enjoy such a regime.

Trade relations and common pan-European economic area is another specific example. In the European Union, the notion of the common economic area does not form part of foreign policy; it covers everything related to market regulation. Whereas the meaning of common economic area or other above-mentioned common areas with Russia remains completely unclear as, in Russia's view, relations with the EU is an issue of foreign and not economic policy. President Putin has said that Russia does not intend to join the $\mathrm{EU}^{49}$. This means that, naturally, Russia is not going to transpose the EU norms to its system. Accordingly, it is hard to imagine a material and not just declared convergence of Russia and the EU.

Therefore, despite high phrases and promising declarations, in 2003-2004 the Russian-EU relations remained in the sphere of quite narrow pragmatic matters. Although the EU was untiringly urging Russia to rectify the state of human rights in Chechnya, to observe the law in the company regulation area, and to ratify the Kyoto Protocol, which would create conditions for entry into force of a new international environmental regime, Russia, apart from the above-mentioned four areas and alleviation of the visa regime, was striving to obtain EU' support in acceding the WTO and to win other additional preferences related to EU's enlargement to Central and East Europe in 2004.

Therefore, one may assume that Russia being a state with imperial ambitions that had not faded out but even became renewed, viewed a closer relationship with the European Union, first of all, not as a creation of a space based on common values and rules but as acquisition of special privileges and exceptions in the relations with the EU. At the same time this would be an important demonstration of success of Putin's governance in the eyes of Russian electorate and a weighty argument and grounds for other CIS states (Ukraine in particular) to rally around Russia, which is becoming a kind of a gate, bridge and intermediary between them and Europe, them and the world!

${ }^{49}$ See: Путин B., (note 34$)$. 
"To Europe together with Russia"-such was the underlying idea of the Common Economic Area project including the four largest CIS states and signed on 19September 2003. It is known, however, that this Putin's project experienced considerable difficulties. Such a system might be attractive to Central Asia and Kazakhstan, but it is doubtful that it would to the Ukraine, Belarus or Moldova situated closer to the European Union, and the EU itself. Although some of Western European states-France or Germany-would prefer dealing only with Moscow, other EU Members States hardly would approve this; finally, this would be contrary to the very nature of the EU.

It was namely this contradiction that was revealed by two crisis events of the second half of 2004: the tragedy of Beslan hostages in September 2004, which was used by Putin as a pretext for striking one more blow to Russia's democracy, and the "orange" revolution in the Ukraine at the end of 2004, which reunited on a common value basis, quite unexpectedly, the USA and Western Europe that had been in confrontation due to the Iraq war and which showed even more clearly the value gap that still exists between the West and Russia.

\section{A Value Gap - Instead of Conclusion}

The international resonance of the killing of schoolchildren in Beslan was two-sided. On the one hand, the world condemned cruelty of terrorists and expressed sympathy with the relatives of the victims. On the other hand, lack of professionalism and helplessness of the Russian services as well as indifference of the authorities toward human lives aroused universal surprise. Russia categorically and with great indignation rejected a wish expressed by Bernard Bot, the Dutch Foreign Minister the Netherlands were holding presidency of the US at that time - to hear an explanation why the hostage-freeing operation demanded so many victims ${ }^{50}$. But the world was surprised even more by President Putin's inappropriate response to the terrorist act. Putin stated that raging terrorism requires strengthening of the state, therefore, abandoning direct governor's elections was the most important thing to do in that situation. According to the new procedures, governors will be elected by the Councils of Subject of the Russian Federation on proposal of the Kremlin ${ }^{51}$.

Thus Putin not just categorically rejected numerous urges to start searching for political measures to settle the bloody Chechen conflict but also expressed a determination to implement further reforms centralising governance as a protection against future terrorist acts, which aroused surprise of both the Russian opposition and the international community. In other words, Beslan's horror became yet another pretext for enhancing the Kremlin's power, which was already great. Putin took another step towards authoritarianism. Therefore, it is not surprising that the issue of

\footnotetext{
${ }^{50}$ Lobjakas A., "Russia: Beslan Hostage Tragedy Leads to Spat with EU”, RFE/RL, September 6, 2004, http://www.rferl.org/featuresarticle/2004/09/6ea40e08-57e6-4d7c-98d7-65360c989f8d.html, 20032005

${ }^{51}$ See more: Путин В., "Выступление на расширенном заседании Правительства с участием глав субъектов Российской Федерации, 13 сентября 2004 года, Москва, Дом Правительства России”, Президент России. Официальный сайт, http://www.president.kremlin.ru/appears/2004/09/13/1514_type63374type63378type82634_76651.shtml, 30032005.
} 
Russia's democracy, which up until that time was avoided at the US and Russian summit meetings, eventually was included in the agenda. On 20 November 2004 during the first meeting of Putin of Bush after the presidential election in the US, held in the corridors of the Asia-Pacific Economic Cooperation's annual summit in Santiago, Chile, the US President inquired about the reform of centralisation of governance carried out by the Russian authorities. According to the news agencies, Putin "went through a very long and detailed explanation" of the political and historical logic, reaching back to the Stalinist period... He made the point the Russian government was trying to develop a democratic style of government "consistent with Russian history and the unique problems that Russia faced as a multiethnic society on a large land mass....But he rejected suggestions he was pushing Russia back to totalitarian rule, but said it was still searching for a model of democracy to match its traditions". ${ }^{52}$

Putin's reference to the Russian history is not a novelty in the consideration and investigation of Russia, however, it should be noted that it is a new thing in Putin's repertoire. Putin had never emphasized Russia's exceptional nature in terms of civilization either in his statements or politics. On the contrary, if one reads Putin's annual report for 2003 to the State Duma mentioned at the beginning of this paper, one would see that it contains no hints to Russia's exceptional nature. On the contrary, the focus is on Russia's efforts toward returning the country to the community of respectable states, to "civilization". However, the logic of behaviour of the political authorities distancing from democracy, concentration of power in one hands, and persecution of dissidents makes the government resort to tricks that are tried and tested though not original. As noted by reporter of Der Standard, an Austrian daily, who provided comments on the Santiago summit, although there are many people in the West who think that Russia can only be controlled by power, "at the same time, for many who are for real democracy, young people in particular - this is a harsh experience. But the farcical nature of Putin's statement is seen very clearly in the Ukraine. During few years of independence, elements of a civic society have appeared in this historical centre of the Russian nation. This has largely contributed to the advancing of a real alternative to the existing system last Sunday during the presidential election and this was done by the Ukrainian citizens despite attempts to forge the election results. Russian cultural strata know perfectly well, too, what kind of democracy they want" 53 .

Indeed, as shown by events, the Beslan crisis was just a prelude to problems that Putin's policy was posing to the European Union and the USA. At the end of the year, the Ukraine issue intruded into the first lines of the international news summaries, which was unexpected for many in both America and Europe. Although, to tell the truth, this could be forecast already in the summer of 2004 when preparation for the presidential election scheduled for 31 October started. The matter is that the

\footnotetext{
${ }^{52}$ Lateline News, "Bush tells Putin of concerns about Russia", Santiago, November 20, 2004, http:/ /dailynews.muzi.com/11/english/1336553.shtml, 20032005.

${ }^{53}$ Kirchengast J. "Die passende Demokratie. Auch im russischen Kulturkreis wissen die Menschen, welche Art von Demokratie sie wollen”, Der Standard, 21 November, 2004, http://derstandard.at/ ?url=/?id=1865865, 20032005 .
} 
election had to resolve the issue of - not more and not less - the Ukraine's geopolitical orientation, which could not be insignificant to Europe and America. Despite that both USA and EU were quite indifferent. Although America has always considered Ukraine's independence to be its strategic priority in the region, now it was preoccupied with Iraq, while relations between the Ukrainian government, more specifically, President Kuchma, with America had gone awry. The European Union, on its turn, had just completed its enlargement and was not cherishing any significant enlargement plans in the nearest future. A special policy of neighbourhood rather than membership was going to be developed in respect of the Ukraine, Moldova and Belarus.

Having noticed that his main geopolitical competitors are passive, President Putin resolved not to miss his chance. If one looks at Putin's agenda in 2004 starting from his election for the second term of office in March, one would be struck by the amount of efforts devoted to the Ukraine. During that period Putin did not consider it a necessity to visit any of the Central and East European countries, while the number of meetings with the Ukrainian President Kuchma in 2004 (if the calculation is correct) reached as much as 10 including as much a 6 Putin's working visits to the Ukraine. This figure could perhaps get into the Guinness record book if only accounting for intensity of meetings of heads of states is kept in it.

It goes without saying that the central concern in the lasting negotiations was to breathe new life into the Common Economic Area project so that it would not suffer the fate of earlier initiatives planned within the framework of CIS. And in the second half of the year, when Kuchma's term of office was nearing end, the Ukraine had to be assisted in ensuring succession of power so that economic integration with Russia would be continued without any obstacles.

Thus it seems that all had been accomplished on Putin's part. According to expert of the Carnegie Endowment for International Peace Anders Åslund, USD 300 $m$ were collected from Russian companies for the support of the election campaign ${ }^{54}$. In addition, Putin sent a team of his advisors and political technologists and during the campaign visited the Ukraine in person twice, agitating for hi favourite Victor Yanukovich. Finally, Putin hastened to congratulate the "winner" on his victory before the official election results were announced.

Putin's haste is understandable. This time as never before he was close to his dream - to rally the former Soviet republics under Russia's wing again. And Putin did not want to miss the opportunity. However, unforeseen obstacles suddenly arose. OSCE observers recorded and published numerous facts of abuse and falsification of election results by the authorities. This provoked mass protests in Kiev. Thousands of demonstrators gathered in the Independence Square, blocked public buildings and paralysed work of the government. This was a real revolution. The authorities had two options - to resort to force or to start negotiating with the opposition leaders heading the demonstrators.

\footnotetext{
54 Åslund A., "Democracy in Retreat in Russia. Testimony before the U.S. Senate, Committee on Foreign Relations", Carnegie Endowment for International Peace, http://www.carnegieendowment.org/publications/index.cfm?fa=view\&id=16550, 20032005 .
} 
Western countries had to make up their minds as well. They had to say whether they acknowledge the election results and welcome Putin's favourite or to state that they support the demonstrators demanding new election. It goes without saying that Russia was sending unequivocal signals of support to the "winner", recognizing no foreign opinions. However, Putin's signals were not effective this time. On 24 November the US Secretary of State Powell stated that the USA did not acknowledge the election results and urged to hold new fair elections ${ }^{55}$.

For Europe it was more difficult to resolve. According to Russia's foreign policy expert Alexander Rahr, it appeared, after emergence of the Ukrainian crisis, that the key EU Member States had shown almost no interest in the Ukraine and processes taking place in it in recent years. Attention was focused on Russia alone ${ }^{56}$. Therefore, the Ukrainian crisis was both a surprise and a headache to Berlin and other West European capitals - and they did not know what to do with it. However, this time even Putin's faithful friends Chirac and Schröder had no opportunity to make allowances for him. Violations of the principles of democracy and fair election were too obvious. This is what Putin's admirer Schröder said: "I am firmly convinced, firstly that the Russian president wants to develop a democracy, and wants to do so out of inner conviction. But that doesn't mean that we cannot ... criticize what has happened in the Ukraine. ${ }^{57}$

Thus, paradoxically, the Ukrainian crisis put everything in their places. It appeared that Russia, despite increased demand for its energy resources and economic recovery, is not becoming more democratic in its internal policy and continues to see its main foreign policy interest in securing its political influence and commercial benefits, which has nothing to do with the universal Western values such as democracy, self-determination of nations, free elections and human rights. Whereas in the West, the USA and the main EU Member States (Germany and France) that had become fierce opponents and had separated politically due to the Iraq war now discovered that they were still united by the same values irrespective of personal dislikes of their leaders.

So if one takes a retrospective look at the period of 2003-2004 one may say with confidence that at that time Western politics performed a real salto mortale from confrontation based on Iraq up to solidarity over the Ukraine. The significance of that for Russia, the Ukraine and a whole range of smaller states in the CEE region is evidenced by the fact that Poland and Lithuania, acting with the EU mandate, succeed in carrying out a mission of intermediation between the confronting Ukrainian political forces and help this country avoid a civil conflict. Eventually, Putin had to retreat at the EU-Russian summit. "While commenting on Ukraine at a RussiaEU summit in the Hague on 25 November, Putin seemed to back down on his previo-

\footnotetext{
${ }^{55}$ CNN.com, "Powell: 'Fraud and abuse' in Ukraine vote", November 25, 2004, http://www.cnn.com/ 2004/US/11/24/powell.ukraine/, 20032005.

${ }^{56}$ Klein B., "Die EU hat sich um die Ukraine einfach nicht gekümmert Interview mit dem Russlandexperten Alexander Rahr", Deutschlandfunk Interview, 24.11.2004, http://www.dradio.de/dlf/sendungen/interview_dlf/324487/, 05032005.

${ }_{57}$ CNN.com, "World pressures Ukraine on poll", November 25, 2004, http://www.cnn.com/2004/ WORLD/europe/11/24/ukraine.reax/index.html, 21032005.
} 
us assurance that the election was indisputably won by Yanukovich. Putin noted that the election is Ukraine's internal affair and added that any election disputes should be resolved by in a legal way. "And we know what the legal way is - all claims should be sent to the court," he said" 58 . As it is known the court ordered to annul the results of the rigged election.

The world press and political analysts assessed the Ukrainian episode unequivocally - as a surprising example of political incompetence and not only as a political defeat of Russia and Putin personally ${ }^{59}$. Anyway, now the most interesting question is how further behaviour of players on this political scene will be affected by the Ukrainian crisis and its settlement in a way desired by most Ukrainians and in line with key Western values. Will political convergence of the USA and major EU Member States continue? Will Russia continue to drift away from the civilized world, with the value gap becoming wider?

For the time being, developments at the end of 2004 do not inspire much hope. A regular meeting of OSCE foreign ministers held on 7 December 2004 in Sofia ended with mutual reproaches expressed by the foreign ministers of the USA and Russia. Sergei Lavrov asserted that OSCE had transformed observation of elections into a tool of political fight and that it was applying a double standard with respect to elections in the West and in post-Soviet states. Whereas Powell rejected these reproaches as totally unjustified and, on his turn, criticised Russia for a failure to fulfil its obligation to withdraw its troops from Moldova and Georgia ${ }^{60}$. Thus, as it was put by the Western press at that time, the wind of the Cold War was felt again. Similar mood prevailed at the grandiose Putin's press conference mentioned at the beginning of this paper. The near future will show whether this is Russia's wilful choice or simply political inertia.

\footnotetext{
${ }^{58}$ Maksymiuk J., "Avoiding a new Cold War over Ukraine", RFE/RL Belarus and Ukraine Report, 1 December 2004, Vol. 6, No. 44, http://www.rferl.org/reports/pbureport/2004/12/44-011204.asp, 23032005.

${ }^{59}$ See: Corvin J.A., “Who lost Ukraine?”, RFE/RL Russian Political Weekly, 12 January 2005, Vol. 5, No. 2. http://www.rferl.org/reports/rpw/2005/01/2-120105.asp, 23032005.

${ }^{60}$ See: Kessler, G., "Powell, Russian Clash on Ukraine", Role of Observers Called 'Political Manipulation"”, The Washington Post, December 8, 2004, p. A13, http://www.washingtonpost.com/wpdyn/articles/A42522-2004Dec7.html, 21032005.
} 